\title{
REFERENCES
}

Barber, R. S., Braude, R. \& Mitchell, K. G. (r953). Chem. \&5 Ind. p. 4 10.

Braude, R. (1950). Brit. F. Nutr. 4, 138.

Braude, R., Campbell, R. C., Lucas, I. A. M., Luscombe, J. R., Robinson, K. L., \& Taylor, J. H. (1955). Brit. F. Nutr. 9, 191.

Jordan, R. M. (I953). F. Anim. Sci. 12, 670.

Kay, H. D. (1953-4). Agriculture, Lond., 60, 564.

Lucas, I. A. M. \& Calder, A. F. C. (1955). Y. agric. Sci, 45, 56.

Robinson, K. L., Coey, W. E. \& Burnett, G. S. (1953). Emp. F. exp. Agric. 2 I, 275.

Taylor, J. H. \& Gordon, W. S. (1955). Vet. Rec. 67, 48 .

Woodman, H. E. (1952). Bull. Minist. Agric., Lond., no. 48, r2th ed.

\section{Fat in Liver and Kidneys of Pregnant Sheep at Different Levels of Nutrition and during Starvation}

\author{
BY D. E. WRIGHT \\ Department of Physiology, Medical School, Newcastle upon Tyne I
}

(Received 28 fanuary I955)

The amount of fat in the liver of pregnant sheep, in animals both on adequate and on poor diets, has been a subject of disagreement amongst workers for many years. The literature is reviewed by Ferguson (1954), who published the results of an experiment in which he kept forty-four ewes under controlled conditions. He studied the effect during pregnancy of two planes of nutrition, one high and the other low, on the liver fat which was determined gravimetrically as the total ether-soluble fraction. At the time of slaughter of these animals, portions of appropriate size were taken from the liver and kidneys and placed in $5 \%$ formol saline. This paper reports the results of a histological examination of these specimens and thus is a study complementary to Ferguson's work.

A summary of the experimental procedure used by Ferguson (1954) is given here; for a detailed account the reader is referred to the original paper. The forty-four ewes were kept on an old pasture and received no supplementary food for 5 weeks before the beginning of the experiment. They were then penned singly indoors except for $5^{-6} \mathrm{~h}$ each day when they were allowed exercise in an uncovered yard. They were fed singly in their pens. The ewes were slaughtered after varying periods, five being killed at random as non-pregnant controls on the day of service of the remainder. For the first 100 days of pregnancy an adequate diet was provided, described as 'high-plane'; from the $95^{\text {th }}$ to the ro2nd day of pregnancy a further six were killed and a random division was made of the rest of the animals into two groups, fifteen in one and eighteen in the other. The first group was kept on the high-plane diet and the second on a lowplane diet which was insufficient for the requirements of the pregnant ewe. The animals from both these groups were killed at varying intervals from the IIgth to the $144^{\text {th }}$ day. From the 138 th day of pregnancy onwards food, but not water, was 
withheld from certain ewes in both groups for periods varying from I to 6 days, while they were confined to their pens without access to the yard.

Apart from providing a sample for histological examination, Ferguson (1954) neither made a study of nor referred to the kidneys of these animals. An investigation into the nature of the changes caused by starvation in the kidney of the non-pregnant rabbit has been made by Dible \& Hay (1940). Increase in chemically determined fat could be correlated with an increase revealed by histological examination in animals starved for 6 days. Visible fat accumulated in the cells and lumen of the wide portions of the ascending and descending limbs of the loops of Henle, the globules being larger in the descending limb. Very slight changes occurred in the cells of the convoluted tubules.

In the kidney of the pregnant ewe Dryerre \& Robertson (I940-I) located fat droplets mainly in the cells of the proximal convoluted tubules as well as in those of the limbs of Henle's loops. Roderick \& Harshfield (1932) considered the infiltration of the convoluted tubules of the kidney of ewes in mild cases of pregnancy toxaemia to be subsequent to that seen in the loops of Henle; they did not encounter casts. Groenewald, Graf, Bekker, Malan \& Clark (194I), however, reported casts in the kidneys of the sheep they studied, as well as glomerular degeneration, and described the changes as a nephrosis.

Portions of the kidneys of the sheep used by Ferguson were examined histologically in order to check the above reports and to see if any further information came to light.

\section{METHODS}

The ewes were eviscerated as quickly as possible after being shot and bled. Portions about $15 \times 5 \times 5 \mathrm{~mm}$ were taken from the left kidney and from the liver. One sample from the left kidney included the cortex and medulla. Four portions of liver were selected to give the widest coverage of the organ to permit the study of the distribution of fat.

Specimens were fixed for $24 \mathrm{~h}$ in $5 \%$ formol saline. Frozen sections were cut at $15^{-20} \mu$ and the fatty material was stained with Sudan IV after counterstaining with haematoxylin.

\section{RESULTS}

Liver. The distribution of fat in the liver, in the four specimens taken from each animal, was, in general, fairly even. Minor variations from part to part were seen in a few specimens, but the extent was not great enough to invalidate an arbitrarry assessment of the amount of fat present in the livers as a whole. The details of the recording system, in terms of which Tables $I$ and 2 are presented, are given in a footnote to Table I.

Typical examples of the extent of fatty infiltration corresponding to the descriptions, are presented in the photomicrographs of Pl. I, which show characteristic fields from specimens of each group.

The control specimens from non-pregnant ewes showed either no fat at all or very 
small quantities within normal physiological limits. No form of abnormality was observed in any of these specimens.

Two of the six animals kept on a high-plane diet and killed after about roo days of pregnancy showed in two instances out of six a just detectable increase in liver fat. The sections showed that it was in the form of very fine droplets distributed over the specimen with a slight tendency for greater deposition in the peripheral portion of the lobules. The droplets were observed both within the cells and in the sinusoids. The specimens were otherwise normal. The specimens from the other members of this group were quite normal. It is of course almost inevitable that, in frozen sections, some fine droplets of fat are transferred from a cut surface of a cell to a nearby space, such as a sinusoid, particularly when much fat is present in a cell. It is necessary, therefore, that statements concerning the disposition of fat in sinusoids, tubules or other similar spaces be qualified to some degree in this respect.

Fatty infiltration was observed in all the samples from the other groups, the extent varying with the degree of dietary deficiency. In the high-plane animals killed at varying times between the I I 9 th and $144^{\text {th }}$ day of pregnancy, but not starved at any time before slaughter (high-plane, unstarved group), small amounts of fat in the form of much larger droplets, better described as globules, could be seen in the cells of the peripheral parts of the lobules. In some specimens the cells appeared somewhat swollen, causing partial occlusion of the sinusoids, some of the latter showing a few fatty globules.

The livers of the corresponding low-plane animals not starved before slaughter (low-plane, unstarved group) showed much heavier infiltration. As well as small globules both within cells and in sinusoids, small fatty cysts, i.e. extracellular fat, were observed, the concentration again being primarily in the peripheral regions of the lobule. A very similar picture was observed in the specimens from the high-plane animals, starved for periods of $\mathbf{I}-6$ days before slaughter (high-plane, starved group), the changes being most marked in those starved for the longer periods. There was, however, a difference, as there were fewer fatty cysts in the latter group and many of the specimens showed a diffuse distribution of fat.

The specimens from the low-plane group of animals starved for $1-6$ days before slaughter (low-plane, starved group) showed the heaviest fat infiltration of all. Fat in the form of diffuse droplets, larger globules and small cysts was seen in most areas, although again predominantly in the periphery of the lobules. Cells were swollen, causing partial occlusion of some sinusoids. In such sinusoids as were clearly visible, fatty material was found.

There was no sign of necrosis in any specimen of liver examined.

The results are shown in Tables I and 2. Values from Ferguson (I954) are given and the histological assessment described here is added. In Table I the assessment represents an 'average' for each group, and in Table 2, in which the results from individual animals are given, the form in which the fat is present is indicated.

Kidneys. The non-pregnant controls showed no material stainable with Sudan IV and the specimens were normal in all respects. The kidneys of the animals kept on 
a high-plane diet and killed at about 100 days were also normal and free from stainable fatty material.

A very slight infiltration of fine fatty droplets, which were fairly evenly distributed, was present in the kidneys of two of the eight ewes on a high-plane diet which were not starved; these specimens were otherwise normal. The specimens from the other members of the group showed no stainable fat and were normal.

Table I. Changes in fat content of liver and kidneys of ewes on high and low planes of nutrition during pregnancy

\begin{tabular}{|c|c|c|c|c|}
\hline & $\begin{array}{c}\text { Non- } \\
\text { pregnant }\end{array}$ & $\begin{array}{c}\text { Iooth day } \\
\text { of pregnancy }\end{array}$ & $\begin{array}{l}\text { High-plane, } \\
\text { unstarved } \\
\text { ( } 3^{8 \text { th- }} \\
\text { 143rd day) }\end{array}$ & $\begin{array}{l}\text { Low-plane, } \\
\text { unstarved } \\
\text { (135th- } \\
\text { 140th day) }\end{array}$ \\
\hline $\begin{array}{l}\text { No. of animals } \\
\text { Liver fat* }(\mathrm{g} / \mathrm{l} 00 \mathrm{~g} \text { fresh } \\
\text { liver) }\end{array}$ & $\begin{array}{l}5 \\
8 \cdot 80\end{array}$ & $\begin{array}{l}6 \\
6 \cdot I 6\end{array}$ & $\begin{array}{l}8 \\
8 \cdot 87\end{array}$ & $\begin{array}{c}6 \\
26 \cdot 7\end{array}$ \\
\hline $\begin{array}{l}\text { Histological assessment: } \\
\text { Liver fat } \\
\text { Kidney fat }\end{array}$ & $\begin{array}{l}\text {-ve } \\
\text { - ve }\end{array}$ & $\begin{array}{l}\text {-ve } \\
\text {-ve }\end{array}$ & $\begin{array}{l} \pm \\
-\mathrm{ve}\end{array}$ & $\begin{array}{c}++ \pm \\
+\end{array}$ \\
\hline
\end{tabular}

Details of recording system. Liver: specimens which had either no detectable fat or fat within normally accepted physiological limits are described as " - ve'; specimens with small amounts of fat over and above such limits as ' \pm ' or ' + ', depending upon the amounts seen; excessive fat distribution principally around periphery of lobule as ' ++ ' or ' ++ \pm '; much fat throughout whole of lobules, even if it predominated in peripheral regions, as ' +++ '. Kidneys: the terms ' \pm ', ' + ' and ' ++ ' are used, depending upon the subjective impression of the total amounts observed in the sections. The degree of infiltration was never great, and thus no sample has the symbol ' +++ '.

* Cf. Table 3 of Ferguson (1954).

Table 2. Changes in fat content of liver and kidneys of individual starved ewes, previously maintained on high and low planes of nutrition, at the end of pregnancy

\begin{tabular}{|c|c|c|c|c|c|c|c|c|}
\hline \multirow[b]{2}{*}{ Ewe no.* } & \multicolumn{7}{|c|}{ High plane } & \\
\hline & 42 & I3 & I I & $3 \mathrm{I}$ & I 5 & 12 & 9 & \\
\hline $\begin{array}{l}\text { Period of starvation* } \\
\text { (days) }\end{array}$ & I & 2 & 3 & 3 & 5 & 5 & 6 & \\
\hline $\begin{array}{l}\text { Liver fat* ( } \mathrm{g} / \mathrm{r} 00 \mathrm{~g} \text { fresh } \\
\text { liver) }\end{array}$ & $5 \cdot 00$ & 20.9 & $24 \cdot 0$ & $24 \cdot 0$ & $14 \cdot 1$ & $13 \cdot 9$ & $20 \cdot 0$ & \\
\hline \multicolumn{9}{|l|}{ Histological assessment: $†$} \\
\hline $\begin{array}{l}\text { Liver fat } \\
\text { Kidney fat }\end{array}$ & $\begin{array}{c}+t \\
-v e\end{array}$ & $\begin{array}{c}+++ \\
++\end{array}$ & $\begin{array}{c}++t \\
\pm\end{array}$ & $\begin{array}{c}++t \\
++\end{array}$ & $\begin{array}{c}++ \\
+\end{array}$ & $\begin{array}{l}++t \\
-\mathrm{ve}\end{array}$ & $\begin{array}{c}+t+ \\
+\end{array}$ & \\
\hline & \multicolumn{8}{|c|}{ Low plane } \\
\hline Ewe no.* & 45 & 50 & 35 & 8 & $2 \mathrm{I}$ & 22 & 47 & 19 \\
\hline $\begin{array}{l}\text { Period of starvation* } \\
\text { (days) }\end{array}$ & I & 2 & 3 & 4 & 4 & 5 & 5 & 6 \\
\hline $\begin{array}{l}\text { Liver fat* ( } \mathrm{g} / \mathrm{100} \mathrm{g} \text { fresh } \\
\text { liver) } \\
\text { Histological assessment:t }\end{array}$ & $32 \cdot 0$ & $2 r \cdot 9$ & 23.9 & $2 I \cdot 9$ & $\mathrm{r}_{4} \cdot \mathrm{O}$ & 10.9 & $20 \cdot 0$ & $32 \cdot 0$ \\
\hline $\begin{array}{l}\text { Liver fat } \\
\text { Kidney fat }\end{array}$ & $\begin{array}{c}+++ \\
+\end{array}$ & $\begin{array}{c}+++ \\
+\end{array}$ & $\begin{array}{c}++ \\
++\end{array}$ & $\begin{array}{c}++ \\
+\end{array}$ & $\begin{array}{c}++ \\
+\end{array}$ & $\begin{array}{l}+ \\
\pm\end{array}$ & $\begin{array}{c}+++ \\
++\end{array}$ & $\begin{array}{c}++ \\
++\end{array}$ \\
\hline
\end{tabular}


Diffuse fatty droplets were observed in some proximal tubules of the low-plane, unstarved group and globules of fat were observed in the cells of some ascending limbs of Henle as well as in the lumen of these tubules. The areas affected were a small proportion of the whole and were found in patches. There was some evidence of slight swelling of the proximal tubular epithelium in a few places.

Small quantities of diffuse fatty droplets could be seen in many areas, particularly in the cells of the proximal tubules of the kidneys taken from the high-plane, starved group of ewes. In general, more fat was to be observed in the kidney as the period of starvation increased, as was seen in liver specimens. Globular fat was identified in the cells of the ascending limbs of the loops of Henle and in some distal tubules. There was evidence of slight swelling of the proximal tubular epithelium in a number of specimens.

As with liver samples, the heaviest fatty infiltration was seen in the specimens from the low-plane, starved groups, and the distribution and form were the same as those seen in the previous two groups, namely diffuse infiltration in the cells of the proximal tubules and globular fat in the cells of the ascending limbs of Henle's loops and distal tubules. Again some slight swelling of the proximal tubular epithelium was seen.

All the kidney specimens, with the reservations made above, presented a normal appearance. Neither casts, hyaline droplets nor vacuolation, as described by Groenewald et al. (194I), were seen, and no evidence of necrosis was found. The fat was almost entirely confined to the cortical regions with very few exceptions. Even in these, the amounts of fat in the medulla were very small. Typical examples from each group are shown in the photomicrographs of Pl. 2.

\section{DISCUSSION}

Liver. The general agreement of the histological assessment of fat with that found by chemical analysis was noted by Ferguson (1954) on the basis of preliminary information available when he was writing his paper. The detailed observations recorded here confirm the earlier impressions, but a close examination of the results in Tables $I$ and 2 reveals certain inconsistencies. It must be remembered, however, that a chemical analysis gives a more accurate estimate of the total amount of fat present than any arbitrary histological assessment on small portions of tissue, the sampling of which may not be random and representative, even with the removal of four pieces from widely different sites. Nevertheless, despite the fact that no commonly used histological technique will reveal all the fat present, the histological method has the advantage that it reveals the distribution of the fat within the liver. It is this distribution, rather than the assessment of the total quantity of fat, that is of prime interest in this paper.

Best, Hartroft \& Sellers (1952) showed that in the liver of dogs, rats and mice kept on choline-free diets for quite short periods, lipids appear as small intracellular droplets. After a further passage of time the fat content increases and the small droplets coalesce to form large spherical masses which distend the cell membrane, displacing the nucleus and compressing it against one wall. When two such liver cells, swollen with fat, are in juxtaposition, the membrane ruptures, giving rise to a fatty cyst 
which can be regarded as extracellular fat; Best et al. (1952) counted as many as sixty nuclei in a single large fatty cyst of this type which thus becomes lined by 'mural cells'. In this condition fat empties into sinusoids and bile canaliculi and the cyst may collapse and be replaced by trabeculae of fibrous tissue. Administration of choline removes intracellular but not extracellular fat.

Many of the specimens examined in the present research showed, as has been indicated, distribution of fat in the peripheral parts of liver lobules similar to that shown by Best $e t$ al. (1952) in their photographs. The stage of small fatty cysts was observed only in the livers of animals in the low-plane, unstarved and the high-plane, starved group, and only the low-plane, starved group showed larger fatty cysts. The question therefore arises whether all these results may not be interpreted on a basis of a dietary deficiency of choline (or any equivalent dietary source of labile methyl groups) and whether the changes would have occurred if such substances had been given as supplements in the foodstuffs. A search of the literature has, however, failed to reveal any figures for the requirements of the ewe, whether pregnant or nonpregnant, for choline or its equivalent. Neither is any information available on the choline content of the rations. It must be emphasized, however, that the histological picture presented in the liver specimens showed striking similarities to those published by Best and his co-workers.

Ferguson (1954) reported a slight decrease of fat from 8.8 to $6 . \mathrm{I} \%$ from the beginning to the rooth day of pregnancy. This difference was not detected histologically, possibly because of the smallness of change; the figures given by Ferguson represent the average for the groups, and it is encouraging to find that the two animals killed at roo days, in which the increase in fat could just be detected in the sections, had the highest percentage of fat (Ferguson, 1953) of all those in the group.

The increase in fat from 6.1 to $8.9 \%$ from the rooth day of pregnancy to the I 38 th-143rd day in the high-plane ewes correlates with the impression obtained from histological examination, which indicated some slight change of fat content from a '-ve' to a ' \pm ' (see note to Table 1 ). Ferguson's results indicated that, at this point (i.e. end of pregnancy), the total amount of fat was about the same as at the beginning of pregnancy, a result not borne out by examination of the sections, which showed more fat at the end than at the beginning.

The marked increase of fat $(26.7 \%)$ found in the low-plane, unstarved animals was also noted in the liver sections which showed much heavier infiltration than in the other groups discussed above. The heaviest infiltration of all was found in the lowplane, starved animals and, although occasional individual disparities will be found, this result in general reflects Ferguson's figures. It is interesting to note the high proportion of the high-plane animals which showed fat in a diffuse form (see Table 2) in response to the starvation from $I$ to 6 days. This finding is, of course, well in keeping with the observation of Best et al. (1952) referred to above.

Kidneys. The appearance of the kidneys in the specimens from Ferguson's ewes showed in no instance such gross damage as Hartroft (1950) describes in the later stages of acute choline deprivation in rats. No sign of necrosis was observed, and, with the exception of two high-plane, unstarved ewes, no generalized diffuse infiltration of 
D. E. WRIGHT-FAT IN LIVER AND KIDNEYS OF PREGNANT SHEEP AT DIFFERENT I.EVELS OF NUTRITION AND DURING STARVATION
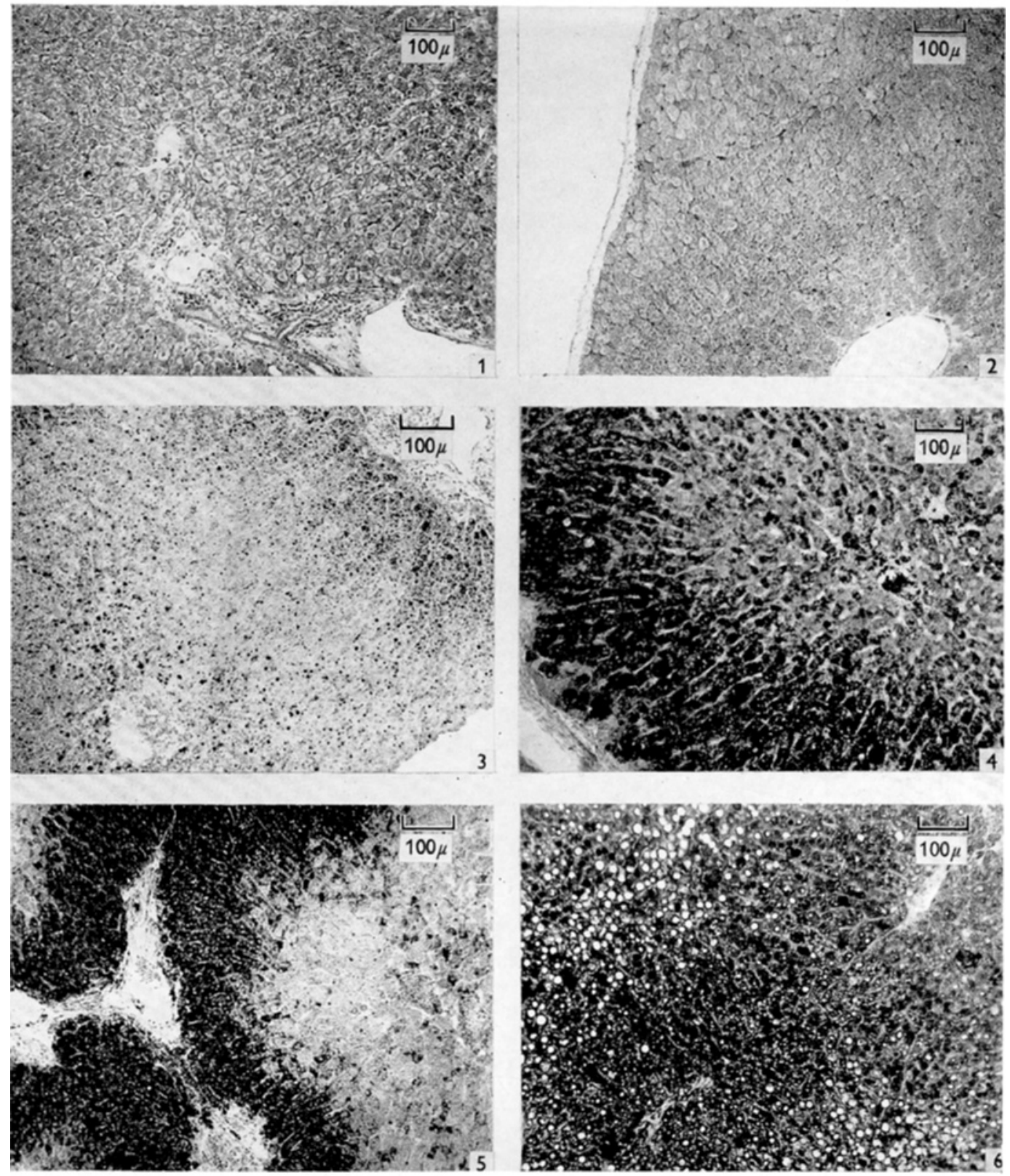

(Facing p. 284)

British Fournal of Nutrition, Vol. 9, No. 3 
D. E. WRIGHT-FAT IN LIVER AND KIDNEYS OF PREGNANT SHEEP AT DIFFERENT LEVELS OF NUTRITION AND DURING STARVATION
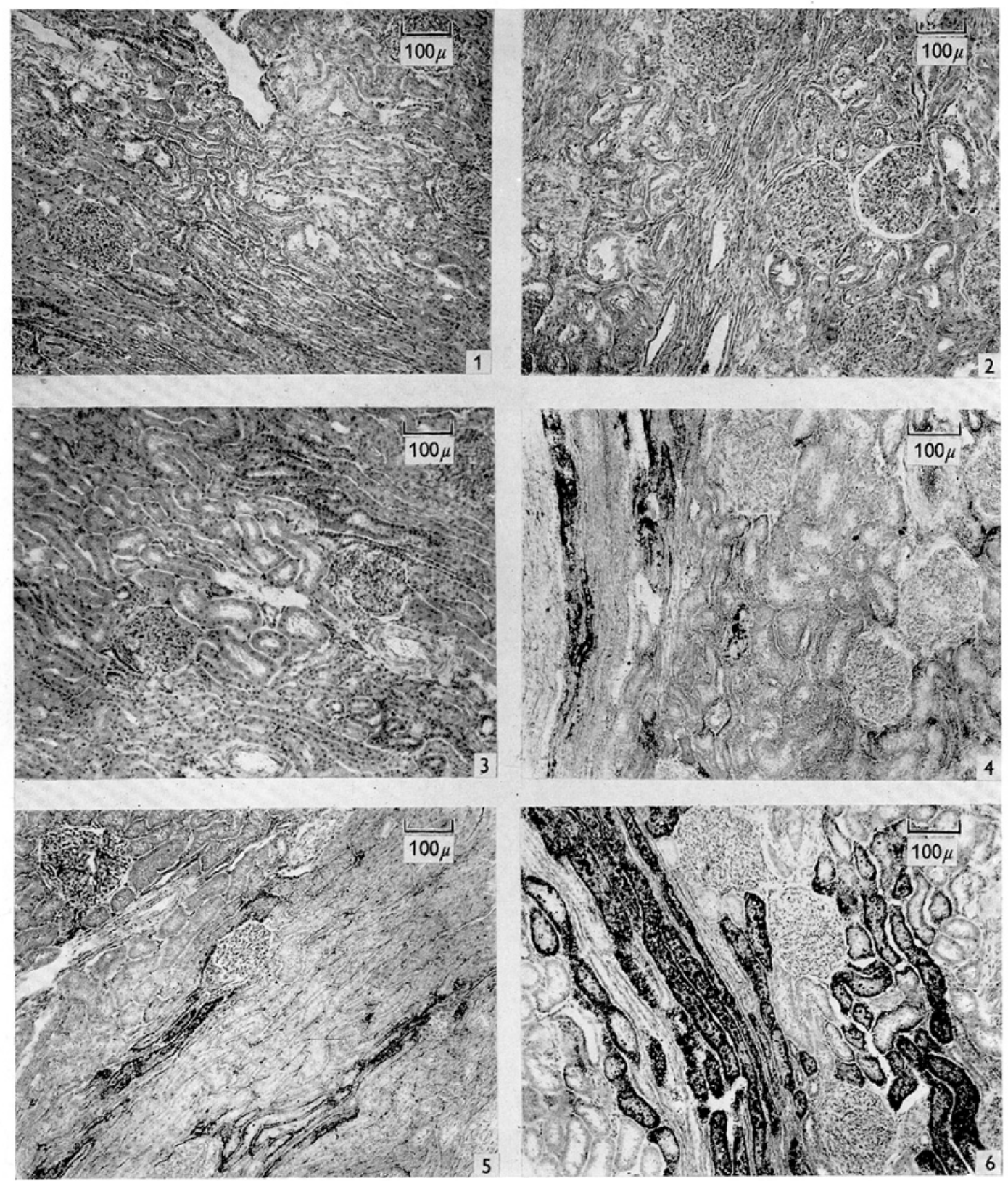

British Fournal of Nutrition, Vol. 9, No. 3 
a whole section was seen; occasional areas of the proximal tubules in particular were found to contain diffuse fat in some of the groups and globular fat appeared in patches in the cells of the distal tubules in the low-plane, starved animals as has been described.

\section{SUMMARY}

I. Samples of liver and kidneys from the forty-four pregnant ewes used by Ferguson (1954) were examined histologically. The ewes had been maintained on a high or a low plane of nutrition during pregnancy and some were killed after periods of starvation varying from $I$ to 6 days.

2. In general, the results from histological examination of the liver specimens paralleled the chemical findings of Ferguson (1954); on a high-plane diet liver fat was not greatly increased except when starvation was imposed. The degree of fatty infiltration in the liver was greater in the animals on a low-plane diet and particularly in those that were starved.

3. A study of the kidney sections showed that, though fat was not so obvious as in the liver sections, the appearances were comparable group for group with the appearances in the liver specimens.

4. Both the liver and kidney specimens were otherwise normal in appearance.

5. The significance and possible relation of these observations to choline deficiency in the diet is considered.

The author wishes to thank N. L. Ferguson of the Department of Agriculture, King's College, for providing the specimens and for much useful discussion. Thanks are also due to Miss Joyce Ballantyne for her valuable technical assistance in the preparation of a large number of the specimens for examination.

\section{REFERENCES}

Best, C. H., Hartroft, W. S. \& Sellers, E. A. (I952). Gastroenterology, 20, 375.

Dible, J. H. \& Hay, J. D. (1940). F. Path. Bact. 5r, I.

Dryerre, H. \& Robertson, A. (r940-1). Y. Physiol. 99, 443.

Ferguson, N. L. (1953). Personal communication.

Ferguson, N. L. (1954). Brit. F. Nutr. 8, 269.

Groenewald, J. W., Graf, H., Bekker, P. M., Malan, J. R. \& Clark, R. (I94I). Onderstepoort f. vet. Sci.

$$
\mathbf{1 7}, 245 \text {. }
$$

Hartroft, W. S. (1950). Proc. r949 Milbank Fd, p. I 44.

Roderick, L. M. \& Harshfield, G. S. (1932). Bull. N. Dak. agric. Exp. Sta. no. 26 .

\section{EXPLANATION OF PLATES}

\section{Plate I}

Photomicrographs of liver sections of ewes, stained with haematoxylin and Sudan IV, exposed with blue filter, peak transmission about $46_{5} \mathrm{~m} \mu$.

$$
\begin{aligned}
& \text { 1. Pre-service control } \\
& \text { 2. After } 100 \text { days on adequate diet } \\
& \text { 3. High-plane, unstarved } \\
& \text { 4. Low-plane, unstarved } \\
& \text { 5. High-plane, starved for } 6 \text { days } \\
& \text { 6. Low-plane, starved for } 6 \text { days }
\end{aligned}
$$

Note. The small white circles in no. 6 are spaces originally filled by fat globules which have been removed in the course of making the preparation.

* For method of assessment see Table I. 
Plate 2

Photomicrographs of kidney sections of ewes, stained with haematoxylin and Sudan IV, exposed with blue filter, peak transmission about $465 \mathrm{~m} \mu$.

I. Pre-service control

2. After roo days on adequate diet

3. High-plane, unstarved

4. Low-plane, unstarved

5. High-plane, starved for 6 days

6. Low-plane, starved for 6 days
Assessment of fat*

- ve

- ve

-ve

$+$

* For method of assessment see Table I.

\title{
The Energy Expenditure and Food Intake of Individual Men
}

\author{
By O. G. EDHOLM AND J. G. FLETCHER \\ Division of Human Physiology, National Institute for Medical Research, London \\ and ELSIE M. WIDDOWSON and R. A. MCCANCE \\ Medical Research Council Department of Experimental Medicine, University \\ of Cambridge
}

(Received 5 February I955)

Within the last 15 years an interest in the importance of calorie expenditure and its relationship to intake has begun to reassert itself after a long interval of time. Broadly speaking there have been two reasons for it: the first has been a desire to find out more about the mechanisms which relate intake to expenditure - what regulates appetite, in fact-and the second an interest in industrial and field physiology. The first detailed study of energy expenditure and dietary intake was made by Bedale (1922-3). Bedale measured the oxygen consumption of roo schoolchildren at twentyfive different activities and the time they spent on these activities. Wiehl (I944) investigated by a diary and interview technique the activities of high-school boys and girls in the United States over a 2-day period. These activities were listed under the headings of sleeping, sitting, and light, moderate and severe exercise, and the mean expenditure agreed very well with the intake, but the individual intakes varied from 50 to $190 \%$ of the expenditures. Keys (1945) criticized these findings as showing the fallacy of computing requirements in this way, and pointed out that individuals who were not rapidly gaining or losing weight must be in calorie balance. This is true, but they need not be in daily balance. Fox (1953) estimated the calorie expenditure and the food intake of members of a village in the Gambia over a period of a year. He measured the oxygen consumption at various tasks and recorded the time spent on the different occupations. Owing to a period of food shortage which coincided with the heavy farming work in preparation for the forthcoming harvest, calorie balance was only achieved over a matter of months, with corresponding losses and gains of weight. 